\title{
Profits and purpose: Organizational tensions in indigenous social enterprises
}

\author{
Mario Vázquez-Maguirre iD, Luis Portales iD \\ Universidad de Monterrey (Mexico) \\ mariovm@gmail.com,portales.luis@gmail.com
}

Received November, 2017

Accepted October, 2018

\begin{abstract}
Purpose: This paper aims to explore the way in which three indigenous social enterprises from Guatemala, Mexico and Peru, solve the paradox of simultaneously producing social and economic value, which creates organizational tensions.

Design/methodology: This research follows a qualitative method based on a case study research strategy. Three different data collection techniques are applied: Analysis of internal reports, direct observation, and semi-structured interviews with relevant stakeholder, mainly employees and managers.

Findings: Indigenous social enterprises deal with organizational tensions by adopting different organizational structures and privileging one dimension over the other (social or economic) in decision making

Social implications: Indigenous social enterprises generate quality of life and reduce historical exclusion patterns by strengthening local economy dynamics through social innovation.

Originality/value: Social innovations, appreciated in different organizational structures, contribute to alleviate the tension that arises from managing entities with double purpose. Also, this research provides evidence of how marginalized groups can overcome exclusion and poverty conditions by creating indigenous social enterprises.
\end{abstract}

Keywords: Latin America, Social entrepreneurship, Social enterprises, Sustainable development, Indigenous communities, Organizational tensions

Jel Codes: L21, L26, L31, M14, Q56

\section{To cite this article:}

Vázquez-Maguirre, M., \& Portales, L. (2018). Profits and purpose: Organizational tensions in indigenous social enterprises. Intangible Capital, 14(4), 604-618. https://doi.org/10.3926/ic.1208

\section{Introduction}

Social innovation is a concept that, from an empirical and theoretical perspective, has been positioned in last decades mainly from its ability to generated new ways of social transformation (MacCallum, Moulaert, Hillier \& Vicari Haddock, 2009; Cajaiba-Santana, 2014; Bitencourt, Bittencourt Marconatto, Barin-Cruz \& Raufflet, 2016). The novelty of the concept and the different perspectives in its study has led it to be considered as a buzzword which introduces the emergence of new arrangements, products or services related to social transformations and satisfaction of social needs, but that does not have a general definition (Pol \& Ville, 2009). 
One of the issues that social innovation attend is the transformation of society for the inclusion of vulnerable groups from an integral perspective (Longo, Gerometta \& Ha, 2005). Practices of social innovation offer a space that includes the voice of the groups that traditionally have been excluded from the development process: indigenous, women, poor, among others. Also, they generate alternatives to increase their quality of life and escape marginalization by their own means and mostly from a local perspective (Fontan, Klein \& Tremblay, 2004, 2005; Pol \& Ville, 2009; Portales, 2015). In this sense, they ways to create these inclusion processes is diverse and rich regarding forms and mechanisms.

Social innovation includes the study of new organizational forms, such as social enterprises, inclusive business models, inter-sectorial alliances or hybrid business-social model (Moulaert, Martinelli, González \& Swyngedouw, 2007; MacCallum et al., 2009; Murray, Caulier-Grice \& Mulgan, 2010; Bitencourt et al., 2016). These novel forms represent a challenge in their design and implementation, characterized by the paradox to produce economic, social or environmental value at the same time without compromising each other (Austin, Gutierrez, Ogliastri \& Reficco, 2006). In response to this paradox, organizations use different types of internal or external arrangements depending on their needs, the social issues they address, and the territory where they operate.

During the process of solving this paradox there is a constant tension in the organization for the need to create two or three types of value at the same time, each one with its own values, principles, norms and considerations in terms of success (Smith, Gonin \& Besharov, 2013). If one organization does not have the capacity to handle this tension, the accomplishment of its social mission or its operation is compromised, leading to the reduction of its impact.

This paper aims to explore the way in which three indigenous organizations, from Guatemala, Mexico and Peru, have solved the paradox that creates organizational tensions by simultaneously creating social and economic value. This was possible through the implementation of different organizational forms and decision making processes, each case can be considered a social innovation itself. Research follow an interpretative perspective, with the intention to understand deeper the phenomena and give voice to the groups that traditionally are considered voiceless.

The paper is divided into five sections. The first analyzes the concept of social innovation in a broad sense, and focuses on social enterprise as an expression of this type of innovation. The second section describes the methodology. The third section exposes the mechanisms and organizational forms that led Ixtlán Group, Wakami and Granja Porcón to solve the tensions between the creation of social and economic value. The fourth section presents the concluding remarks, focusing on the organizational forms used by indigenous social enterprises to solve the tensions that this paradox generates.

\section{Social innovation and social enterprises: An alternative to address social issues}

Social Innovation integrates two constructs that emerge in different disciplines and are complex by themselves in their conception (Cajaiba-Santana, 2014). Innovation is a concept studied from management theory, but is mainly related with all the creation and implementation of something new to improve the way in which things are done: products, services, processes, etc. (Pol \& Ville, 2009; Parker, 2012; Cajaiba-Santana, 2014; Howaldt, Domanski \& Kaletka, 2016). Social is a more complex concept in general, but in this context, it is related with the issues and challenges that some society faces to increase the living conditions of all their inhabitants from an inclusive perspective (Fontan, Klein \& Tremblay, 2004, 2005; Portales, 2015; Bitencourt et al., 2016). United Nations made an effort to define the main issues that societies should attend by 2030 through the Sustainable Development Goals (SDG). These goals include no poverty, zero hungry and ensuring healthy lives and promoting well-being for everyone (United Nations, 2015).

Social Innovation refers to new solutions that seek to improve living conditions of groups excluded and meet their social needs in a more effective way than current solutions; at the same time that it increases the capabilities, relationships and process of societies (Murray et al., 2010; Cajaiba-Santana, 2014; Morais-Da-Silva, 2016). Under this definition, social innovation must include something novel in the satisfaction of some social need; it could be incremental or disruptive and in it has to be more effective and efficient. Also, social innovation should be oriented to remove the barriers that promotes and preserve exclusion and their consequences, and it should 
enhance society's capacity to act at every level, not only in the vulnerable or marginalized group, but also in the groups or people that generates patterns of exclusion. In this sense, most of social innovations include the integration of several groups or organizations from different sectors, sizes, and levels of operation to increase their impacts and to be more effective in delivering a social solution.

These innovations seek to offer a novel way to address social issues within the territory, such as poverty alleviation or injustice (Bizberg, 2010); the remotion of barriers that produce exclusion (Austin et al., 2006), or the existence of a common ideology that allows the rise of new social movements (de Sousa Santos, 2001). In social innovations the organizational actor has a leading role as a legitimate representative of society's interests in articulating bottom-up initiatives and social relations, and also in identifying non-satisfied social needs and in innovative ways (Morais-Da-Silva, 2016).

Social innovations can take several forms in their implementation, such as new products, services, platforms or organizational forms; and they are not particular of any sector of the economy, they can emerge in non-profit, private, public organizations, or even the informal sector (Caulier-Grice, Davies, Patrick \& Norman, 2012). Most social innovations integrate actors from different sectors to increase their impact and scalability, which is one of the main features of social innovation (Westley \& Antadze, 2010; Portales, 2015; Le Pennec \& Raufflet, 2016; Morais-Da-Silva, 2016). Additionally, to the social innovations created by private and social sectors, social enterprises have emerged as a new type of social innovation and that now constitute a new sector. This sector develops initiatives oriented to the creation of social and economic value from their conception.

\section{Social enterprises as social innovation}

Social entrepreneurship is a concept that originated in the eighties and had become more relevant in the twentyfirst century. One of the reasons is the connection of two constructs that seemed to be antagonistic: entrepreneurship and social (Peredo \& McLean, 2006; Yunus, 2009; Friedman \& Desivilya, 2010). Social entrepreneurship is a way to achieve the generation of economic wealth while addressing social issues in a sustainable way (Campbell, 1998; Mair \& Martí, 2006; Dees, 2007). The theoretical construction of this novel concept has been carried out mainly through the documentation of empirical cases about social enterprises (Peredo \& Chrisman, 2006; Vázquez-Maguirre \& Portales, 2014). Social enterprises generally arise in contexts of marginalization and exclusion, where market barriers prevent these groups from getting employment opportunities and selling their products. Basic infrastructure in this regard is usually scarce, increasing poverty circles (Bird, Hulme, Moore \& Shepherd, 2002; Kay, 2006). For this reason, the most common objectives of these companies involve reducing poverty by creating employment, providing a product or service to a disadvantaged group, specialized training for unemployed people, producing high value-added goods, and creating markets for these products (Dees, 2007; Defourny \& Nyssens, 2010).

These entities combine the efficiency, innovation, and resources of profit-making entrepreneurs with the passion, values, mission and concerns of nonprofit organizations (Smith et al., 2013). Citizens or social groups, usually recognized as social entrepreneurs, create social enterprises with the intention to provide sustainable solutions to social needs (Santos, 2012). The collective quality of such organizations facilitates democratic governance while pursuing the common good. This sense of community fosters alliances among different organizations with similar social, economic, institutional and/or environmental missions (Vázquez-Maguirre \& Portales, 2014). Under this context, social enterprises offer a sustainable solution that enables the community to use its autonomy, creativity, and solidarity to overcome the problems it faces (Vázquez-Maguirre, Portales \& Velásquez, 2018). The solution generated by social enterprises usually creates new patterns in market access, leadership, local empowerment and creates cross-sector partnerships (Santos \& Eisenhardt, 2009).

Most of the studies of social enterprises focus on the impact that each one creates in specific contexts or territories enhancing the idea that these organizations are mechanisms to solve the society's $m$ ain issues (Dey \& Teasdale, 2013). These studies give special attention to business or intervention models that organization use to create social, economic and environmental value (Di Domenico, Haugh \& Tracey, 2010; Kostetska \& Berezyak, 2014; Vázquez-Maguirre et al., 2018). 
However, there are a few studies that focus their attention in the paradox and tension, at organizational and epistemological level, in the creation of several types of values at the same time (Dey \& Steyaert, 2010; Smith et al., 2013). The paradox can be solved through the adoption of different organizational forms, which could be defined in terms of the model and school of thought that enterprises adopt (Defourny, 2001; Defourny \& Nyssens, 2008; Chambers, 2014). To get a better understanding of these schools, they could be divided into three economic approaches, which is a continuum in terms of the economic paradigm on which they are based, from social economy to inclusive capitalistic economy (van Kemenade \& Favreau, 2001; Portales \& Arandia, 2015) (Figure 1).

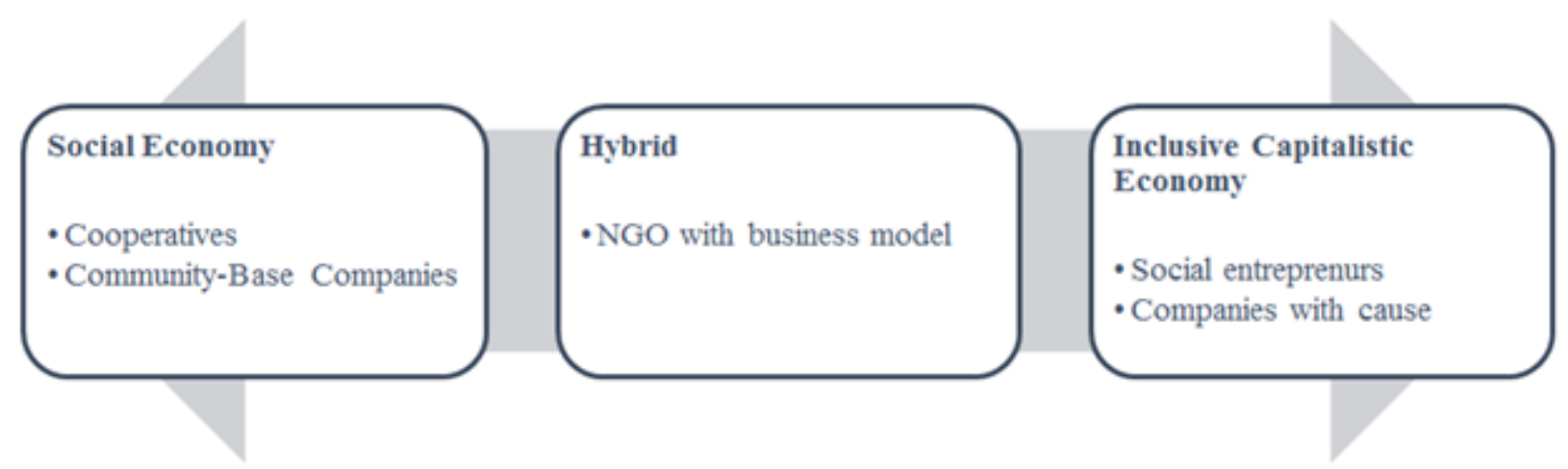

Figure 1. Approaches of Social Enterprises according to their economic paradigm (Portales \& Arandia, 2015)

In the social economy, organizations' main purpose is the attention to some social issue and not the generation of economic value. Most of these organizations seek to respond to social exclusion through the generation of cooperatives or community-based companies as a source of employment for vulnerable groups (Nyssens, 2006). Under this approach, the poor or vulnerable group are shareholders in the company and seek the active participation of the community in decisions making (Vázquez-Maguirre \& Portales, 2014; Vázquez-Maguirre et al., 2018). This approach concentrates on the generation of horizontal and inclusive organizational dynamics, where the beneficiaries are responsible for the income generation for overcoming their poverty or vulnerable conditions (Mikami, 2014). Success is defined regarding construction of local capabilities, developing sustainable strategies, and the reduction or eradication of exclusion.

Inclusive capitalistic economy considers social entrepreneur as an agent of change or changemaker (Defourny \& Nyssens, 2010). In this approach individuals or organizations create social enterprises with the intention to create social and economic value through the development of some product or service for specific markets (Austin et al., 2006). The success of social enterprise depends on its capacity to position its products in some market (Portales, 2015). Between the social economy and the inclusive capitalistic economy approach, there is a hybrid perspective. Hybridity is characterized for the operation of business by Non-Governmental Organizations (NGO) or Non-profit Organizations with the objective of having a constant source of income, allowing them to keep their operation and the creation of social value (Defourny, 2001; Bacchiega, \& Borzaga, 2003; Wei-Skillern, Austin, Leonard \& Stevenson, 2007; Portales, 2015). This approach is characterized by the creation of double or hybrid structures within organizations (Portales, Arandia \& García de la Torre, 2015); one for the achievement of social mission by the creation of social value, and the other oriented to the generation of profitable business model (Bacchiega \& Borzaga, 2003; Defourny, 2001; Wei-Skillern et al., 2007). Creation of these structures makes operations more complex and strengthens the tension between the creation of economic and social value.

Due to their historical context of social exclusion, these impacts are more visible in rural indigenous communities (Foley, 2003; Berkes \& Adhikari, 2006). In this sense, the number of social enterprises in indigenous communities has grown significantly worldwide (Paton, 2003). The efforts to systematize, measure and document these initiatives, and their economic, social and environmental impacts have been isolated (Díaz Foncea, Marcuello \& Marcuello, 2012), especially in rural and indigenous areas (Orozco-Quintero \& Berkes, 2010). Most of the analysis of indigenous social companies reveal the elements that these communities 
developed to create impact, economic wellbeing, and sustainable development; and the mechanisms they use to achieve their goals (e.g. Vázquez-Maguirre et al., 2018; Vázquez-Maguirre \& Portales, 2014). But there is a lack of evidence about the different mechanisms they use to manage the tensions related to the dual purpose mission. To explore this gap, as well as provide studies oriented to systematize, measure, and document social enterprises in rural and indigenous areas, three cases of indigenous social enterprises in Latin America are examined.

\section{Methodology}

This research followed a qualitative method based on a case study research strategy. This approach was based on three aspects. The first is the complexity posed by social enterprises and the need to contextualize each of their actions; most of the studies on social enterprises has this nature (Anderson, Dana \& Dana, 2006; Hockerts, 2010). Second, the indigenous component demands an understanding of the different indigenous cosmovision, and how it affected the formation and management of these social organizations. The third aspect is the exploratory stage of the study of social enterprises.

Fieldwork was conducted from October 2011 to May 2012 in the community of Ixtlan, from February to March of 2013 in Granja Porcón, and in December 2016 in Wakami. Three different data collection techniques were used. The first was the analysis of internal reports, internal work regulations, code of ethics, and material created to keep their stakeholders informed about activities and results. The second data collection technique was direct observation both in each social enterprise and the community. Field notes and photographs help appreciate the way of living in these communities and how the companies operate. Finally, semi-structured interviews were conducted with relevant stakeholder, mainly employees and managers. The interviews were divided into four sections: Introductory questions about background, economic aspects, social aspects, and environmental aspects.

\begin{tabular}{|c|c|c|c|}
\hline & Stakeholders & Interviews & Other considerations \\
\hline \multirow{6}{*}{ Ixtlán } & Employees & 30 & \multirow{6}{*}{$\begin{array}{l}25 \text { of them from the community } \\
\text { Three of them were still advisors } \\
\text { Seven of them from the community }\end{array}$} \\
\hline & Former employees & 7 & \\
\hline & Managers & 8 & \\
\hline & Government & 2 & \\
\hline & Financial institutions & 2 & \\
\hline & Community (not employees) & 4 & \\
\hline \multirow{3}{*}{ Wakami } & Partners: indigenous women & 10 & \multirow[t]{3}{*}{ From five different indigenous communities } \\
\hline & Managers & 2 & \\
\hline & Employees & 4 & \\
\hline \multirow{3}{*}{$\begin{array}{l}\text { Granja } \\
\text { Porcón }\end{array}$} & Employees & 10 & \multirow[t]{3}{*}{ Everyone lives in Granja Porcón } \\
\hline & Managers & 2 & \\
\hline & Partners: Yanacocha & 2 & \\
\hline
\end{tabular}

Table 1 . Interviews by stakeholder

The composition of the interviews by social enterprise and stakeholder is illustrated in Table 1. Half of the interviews were women. The transcripts account for more than 600 pages; the interviews range from half an hour to two and a half hours, the average interview is 50 minutes long. The criteria for selecting the interviewees were, in order of importance, visibility, specialized knowledge, and recommendations. Since these communities are small and sometimes cautious of foreign people, a direct list of relevant positions within the organization was provided to the general manager. He or she directly approved the interviews and suggested additional personnel. There was a couple of group interviews, in Grupo Ixtlán and Wakami, who involved three and four interviewees respectively. These employees felt more comfortable talking in groups than individually.

The interviews were held until theoretical saturation was found in the respondents and the information provided by the different stakeholders converged (Golafshani, 2003; Harrison, Macgibbon \& Morton, 2001). This information was further triangulated with direct observation and secondary data. The initial process was to classify or label units of data, inductively, as parts that belong to a more general phenomenon. Some categories that emerge were: structure, benefits, profitability, governance, culture, stakeholders, social innovation, conflicts, values, procedures, growth strategies, sustainability, and partnerships. Then, through abstraction, comparison, and integration, categories merged and were grouped in four dimensions: social, economic, organizational 
structure, and impacts. The data was not analyzed in a sequential manner but moving back and forth between stages (iteration) as suggested by Spiggle (1994).

\section{Results}

Social enterprises have different mechanisms to deal with the tension that arises from their dual purpose: to fulfill their social mission while generating enough income to have financial independence and sustainability. In this paper we present three cases from Latin America that involve different responses to this tension: Grupo Ixtlán, Wakami, and Granja Porcón.

\subsection{Grupo Ixtlán}

The community of Ixtlán consists of around 3,000 people, who are descendants of the Zapoteco ethnic group. Ixtlán is located 62 kilometers north of the state capital of Oaxaca, and 525 southeasts of Mexico City (see Figure 1). In 2014, 61.1\% of Mexican households in rural areas were poor (compared to $41.7 \%$ in urban areas), and a third of them lived in extreme poverty. Particularly, indigenous communities observe the highest level of poverty in the country: $73.2 \%$ (CONEVAL, 2015). Most indigenous communities in Mexico have autonomy regarding the election of its authorities through a system of usos $y$ costumbres (customs and habits).

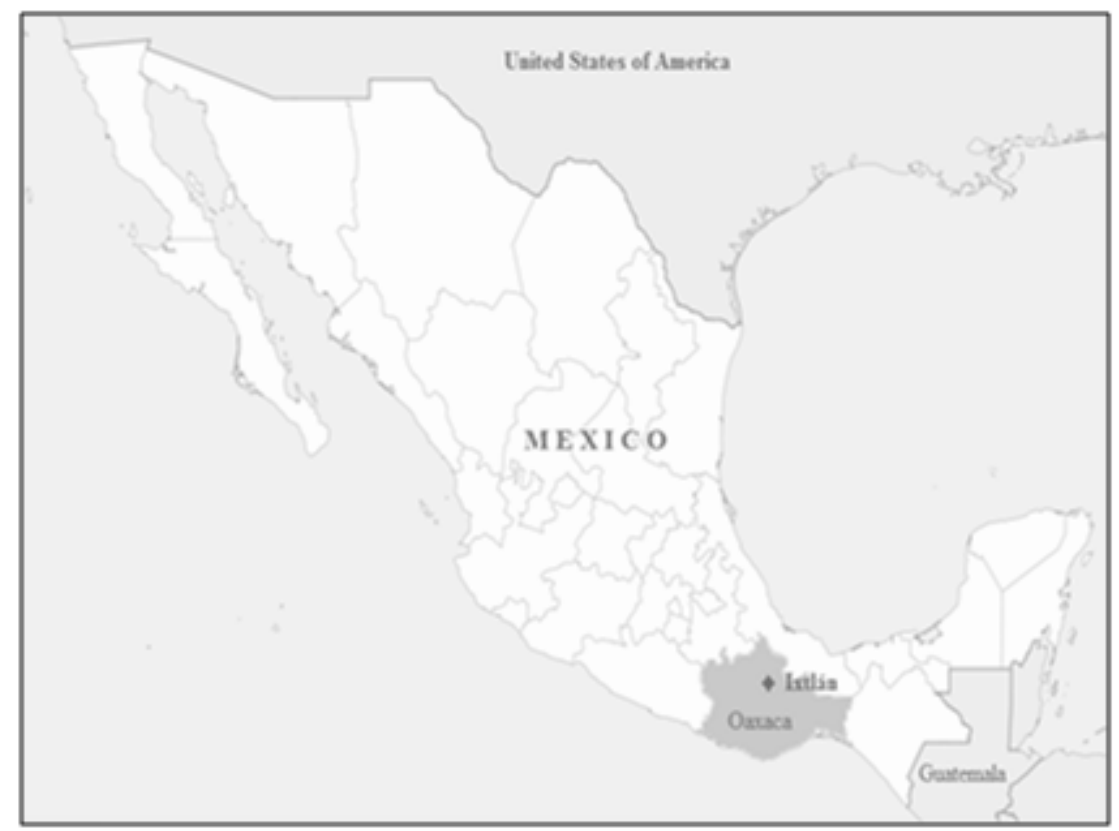

Figure 1. Location of Ixtlán (Mexico). Source: Vázquez-Maguirre et al., 2018.

From early 1950's to late 1980's, foreign and state companies arrived to Ixtlán and nearby communities to exploit timber resources but failed to bring prosperity and wellbeing to the region. In 1988, after several boycotts that forced the companies out of the region, Ixtlán decided to create the Forestry, Land and Communal Services Unit (FLCSU). The mission of the organization was to generate decent jobs and generate wellbeing among the community. The enterprise, led by a Commissariat of Communal Goods (CCG), focused on timber exploitation, but it also had cattle, agriculture, and transportation divisions. New departments were added as the community demanded more services and new jobs: a hardware store, a gas station, and a microfinance institution. In 2008, the CCG decided to split the company into independent enterprises since the management of such a diversified entity was becoming problematic, and the organizational tensions needed to be addressed with a different organizational structure (see Table 2). The president of the CCG explains the main problem: "We did not know which project was profitable and which was not, they [managers] all said that they were generating profits when perhaps one or two covered the losses of all the others... so we split the company into seven enterprises". 


\begin{tabular}{|l|l|l|}
\cline { 2 - 3 } \multicolumn{1}{c|}{} & Business Units/Departments & Mainactivity \\
\hline \multirow{4}{*}{ Ixtlán } & FLCSU & Sawmill and furniture factory \\
\cline { 2 - 3 } & UNFOSTI & Timber exploitation \\
\cline { 2 - 3 } & Technical Forest Services & Sustainable management of the forest \\
\cline { 2 - 3 } & Tienda Comunitaria Ixtleca & Building materials and hardware store \\
\cline { 2 - 3 } & Gasolinera Comunidad Agraria & Gas station \\
\cline { 2 - 3 } & Ecoturixtlán SPR de RI & Eco-tourism park \\
\cline { 2 - 3 } & SOFOM Ixtlán & Productive micro-lending \\
\hline \multirow{4}{*}{ Wakami } & Comunidades de la Tierra & Manufacturer of fashion accessories \\
\hline \multirow{4}{*}{ Porcón } & Kiej de los Bosques & Trade and fashion design \\
\cline { 2 - 3 } & Forestry & Forest management, sawmill, and factory \\
\cline { 2 - 3 } & Tourism & Zoo, horse rides, eco-cabins, restaurant, handicraft \\
\cline { 2 - 3 } & Dairy & Production of milk, cheese, and yogurt \\
\cline { 2 - 3 } & Pisciculture & Trout farm \\
\cline { 2 - 3 } & Agriculture & Production of potato, wheat, barley, etc. \\
\cline { 2 - 3 } & Livestock & Mainly alpaca, vicuna, cattle, sheep \\
\hline
\end{tabular}

Table 2. Business units or departments at Ixtlán, Wakami, and Granja Porcón

As Grupo Ixtlán has diversified and grow, organizational tensions have emerged as consequence of its dual purpose. This social enterprise seeks to generate a positive impact on its main interest groups, however, the empowerment mechanisms it has designed has generated operating costs that exceed those of its competitors. Grupo Ixtlán usually provides 220 jobs; most of them with legal benefits: social security, housing, paid vacations, productivity and punctuality bonuses, profit sharing, retirement pension, paid overtime, and 48 hours per week schedule. Only 39\% of the Mexican population has such benefits, and only $25 \%$ in the State of Oaxaca. This has generated a loss of competitiveness in the furniture market. Although Grupo Ixtlán promotes the indigenous origin of its products and emphasizes the environmental and social work that it performs, most of the customers are not willing to pay an additional price for these attributes. The consumer still does not value the sustainable management of timber resources (the company has the Forest Stewardship Council certification), so the final decision is mainly price driven. This has generated a lot of tension in Grupo Ixtlán, since the furniture they manufacture is the only product that sells outside the community. In recent years there have been voices in the organization that seek to privilege the social part, and others that privilege profit generation (quotes about utilities). This tension is a recurring point of debate in the assemblies, and it has not been completely resolved. However, management decisions usually end up being driven by the pursuit of profits over social value.

In 2012, the organization has decided to move part of the furniture factory outside the community. The weather in Ixtlán does not favor the product's varnishing process, which derived in having to carry out the same process two or three times. This problem has been addressed in a variety of ways to ensure quality, yet managers knew that the optimum solution to reduce costs was to move production to a warmer climate, and closer to the points of sale. This decision meant losing 30 jobs in the community, in addition to look for new suppliers near the new plant, that is now situated in the vicinity of Oaxaca City. Likewise, the design of new products and furniture collections will move from the community to this new place, taking another dozen job outside the community. Grupo Ixtlán does not forget its mission, but managers understand that it should privilege profits (by reducing the cost of production) over purpose to be able to compete in the industry of wood furniture. Sacrificing the creation of social value in the community seeks to strengthen companies in the economic dimension and, in the long term, the expected growth would allow to recover the jobs that were lost in the community (its main group of interest).

This case shows that when faced with high competition scenarios, social enterprises must make decisions that sometimes affect their social work, and that seem counter intuitive for them. However, the idea of reducing costs, complemented by the search for new markets where the attributes of Grupo Ixtlán are valued, seeks to provide financial viability to the organization to ensure its continuity over time. The president of the CBC explains why: "I am convinced that the company has to generate economic profits, sacrificing a bit the social part, to have money for social issues. There cannot be benefits and loans if the company is in red numbers". 


\subsection{Wakami}

Wakami is a social enterprise that deals with the tension between purpose and profit in an innovative way, changing its organizational structure to reduce it to a minimum. Wakami was created 10 years ago with the mission of empowering indigenous women in Guatemala to fulfill their dreams: a decent house, a dignifying job, and a better future for their children (see Figure 2). Wakami produces and exports fashion accessories (necklaces, bracelets, bags) to Mexico, United States, several European countries, and Japan. Its innovative business model employs women's groups in different indigenous rural communities in Guatemala to manufacture these products. In addition to a decent salary, Wakami provides these women with technical advice, supplies, welfare talks, scholarships to their children, health programs, and green products to increase their quality of life. The organization still does not reach the point of financial balance, so it seeks arrangements with large Guatemalan companies to sponsor the training cycles of these groups of indigenous women.

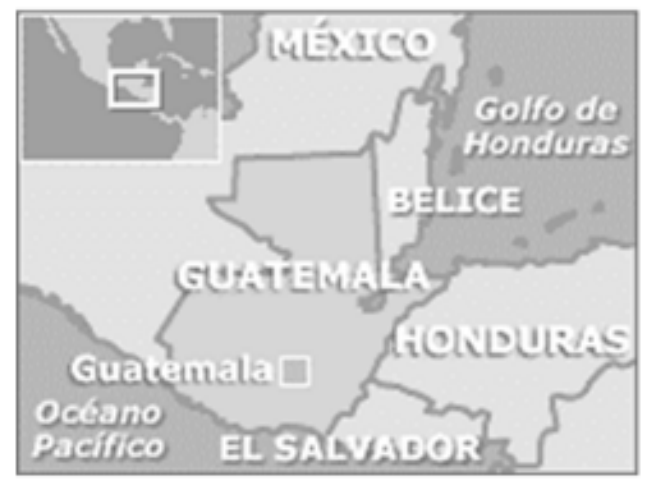

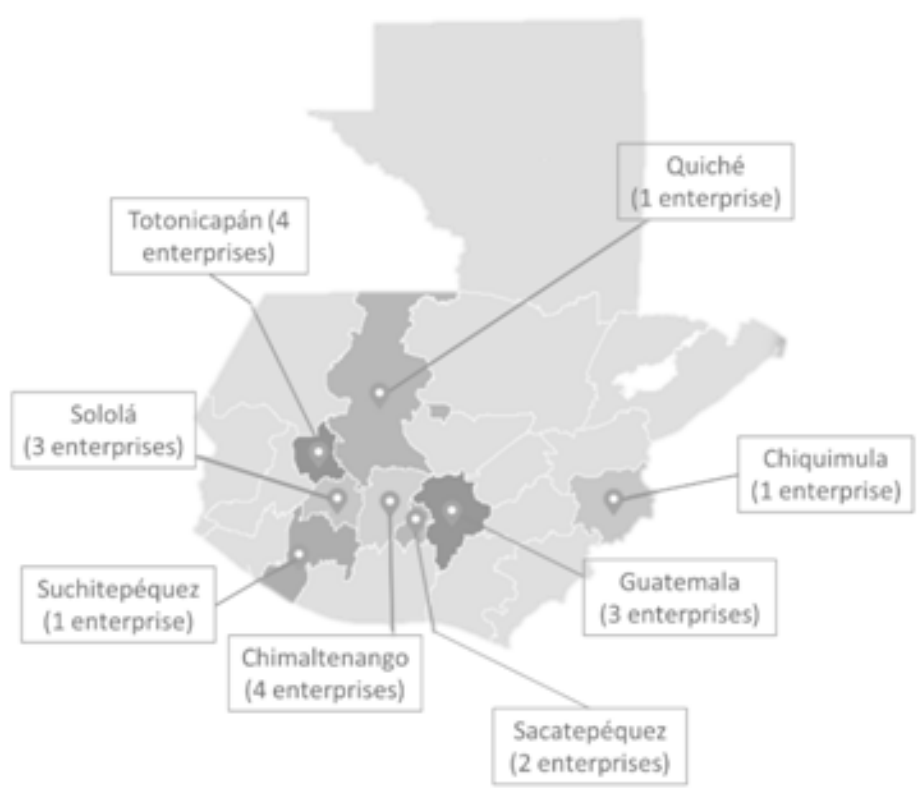

Figure 2. Location of the communities where Wakami operates (Guatemala). (Elaborated by the authors with information of Comunidades de la Tierra, 2018)

When Wakami faced the growing tension between the creation of social value to fulfill its mission, and the search for profit that would allow Wakami to be financially viable, the company decided to change the organizational structure. The general manager of Comunidades de la Tierra explains the issue: "Managers realize that a different organization was needed to manage the social part. One entity would not be able to generate profits and create enough social value to accomplish the mission". She adds that the generation of social value demanded special capabilities, so the best solution was to change the structure.

Eight years ago, the organization was divided in two companies. The first one, Kiej de los Bosques, is a commercial company, guided by the principle of profit maximization, dedicated to the design and trade of fashion accessories. This company does not deal with creating social value for the indigenous women, it is committed entirely to its customers and distributors. In this sense, the employees have a business profile oriented to the exploitation of opportunities around the world, seeking business partners to open market in new countries. They also have a fashion team that designs collections aligned to global trends.

Kiej de los Bosques has defined financial metrics: utility margins, profitability, reducing operating costs, which allow it to focus entirely on achieving those financial goals without worrying about the mission of Wakami. Kiej de los Bosques obtains its products from Comunidades de la Tierra, the second entity of this social enterprise. This company has a clear social goal, and its mission is to increase the levels of well-being of its partners: indigenous women's groups. Comunidades de la Tierra trains indigenous women on how to produce these 
fashion accessories, supply the inputs, controls quality, find new groups of indigenous women around Guatemala, and promote social welfare programs for these groups. Comunidades de la Tierra has nutrition programs, a system of scholarships for elementary school, and a program to supply of green products such as natural water filters, and ecological stoves.

The metrics of this entity are social: percentage of children that goes to school, number of women working as partners, number of communities reached, and average income by partner, among others. Wakami is improving the lives of 530 families through 19 groups of women operating in eight communities around Guatemala. The leader of one of the groups analyzes how Wakami improved the lives of its members: "Before, we do not have enough income to buy school uniforms [so children drop out of school], right now I see that most if not all have their children in school, better nutrition, and an improved house with cement floor and walls made of bricks".

Each of the companies has clear objectives and indicators, which helps reducing the tension to minimum levels. In Wakami's case, the response to the tension between purpose and profit was a change in structure; according to the qualitative work done through in-depth interviews, this response has been successful. Wakami is made up of two different organizations, which share the 9th floor of a building in an exclusive area of the Guatemalan capital, where indigenous women arrive to deliver their products and receive the inputs to produce a new purchase order.

\subsection{Granja Porcón}

Granja Porcón consists of 1200 inhabitants, mainly of descendants of the Canari-Cajamarca ethnic group; it is in the department of Cajamarca, province of the same name, in the northern highlands of Peru and one of the poorest in the country (see Figure 3). In 2015, Cajamarca headed the list of Peruvian departments living in poverty (50\% of its population) and extreme poverty (between $17 \%$ and $24 \%$ ) (INEI, 2016). The main economic activities of the department, as in the rest of rural areas, are agriculture, livestock, and mining. Many of its inhabitants end up migrating to the coastal cities in search of better employment opportunities.

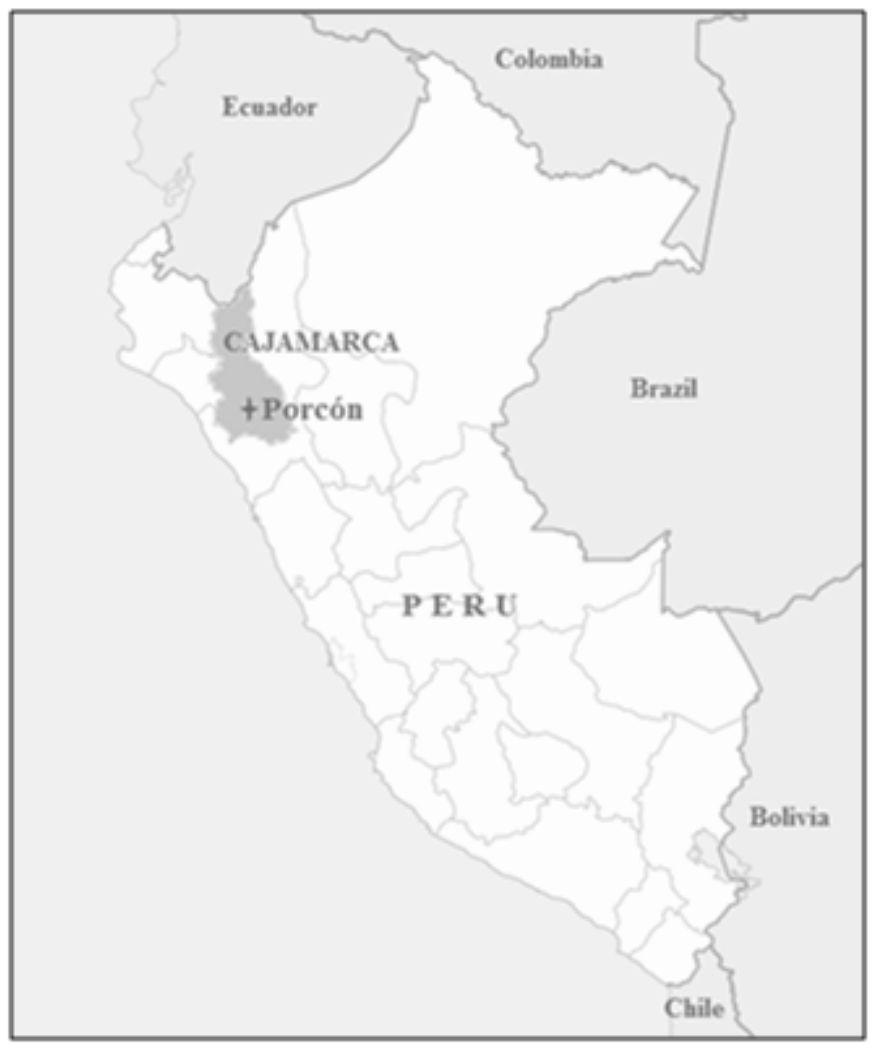

Figure 3. Location of Granja Porcón (Peru). (Vázquez-

Maguirre et al., 2018) 
A military-led agrarian reform in 197 imposed a new form of production organization that worked as a cooperative, ending government subsidies. In the early 1980s, as most of these entities failed, and a new enterprise is formed: The Agricultural Cooperative Atahualpa Jerusalem, better known as "Granja Porcón", composed of 53 members, who adopt the Baptist religious values to rule the activities of the entity. The mission of this organization is to provide decent jobs to the members of the community. From the beginning, the leaders of this organization started foresting the surroundings, they believe that pine trees could bring them the jobs they needed to increase their wellbeing. The general manager of the organization recalls the story: "Based on Isaiah 41:19 in the Bible, which says: in the solitudes I planted cypresses and pines. Then I tell you that we must forest... that is the only way we are going to have enough jobs for all of us".

They forested around 7,000 hectares. In 1990s, the entity, which was focused on timber exploitation, started growing to other industries, although they did not see the need to split or create a new organization. They organized themselves in different departments: forestry, tourism (a zoo, cabins, restaurants, and horse riding tours), dairy, pisciculture, agriculture, and livestock, with the first two contributing with more than two-thirds of the organization's income. By 2014, Granja Porcón had 200 permanent jobs and the same amount of temporary jobs.

As most social enterprises, Granja Porcón struggled with the tensions generated by the need to fulfill its social purpose, and at the same time generating enough profits to achieve financial sustainability. Granja Porcón responded differently from the two previous cases. This social enterprise decided to privilege the social part in every decision. The head of the department of tourism believes that, if the objective of Granja Porcón is "to watch for the future of our children and ours, and to promote social development in our communities", then the social dimension must be central in every decision. When faced with the decision of reducing costs to gain competitiveness, Granja Porcón decided to give up economic growth. Instead, this company has sought alliances with large companies to finance its growth and gain expertise. This has let it continue with its focus on the social part.

It currently has partnerships with two multinational companies: Newmont and Nestle. The first multinational has operations next to Granja Porcón, in the Yanacocha mine, the largest in Latin America in gold production. Yanacocha has sought projects that legitimize its operations in the area, which is known for its resistance to foreign companies. A couple of these projects have benefited Granja Porcón: the construction of a set of cabins to promote ecotourism, and the construction of aquaculture farms to grow trout. Both projects have generated jobs and economic spills. In exchange, Newmont can use some resources it needs to operate: water and a portion of the land belonging to the social enterprise, which presumably has gold deposits. Similarly, Nestle has found in Granja Porcon a partner that ensures the supply of milk in the region, while the company ensures training and equipment to increase the quality of its products. Privileging the social part has had its negative consequences: the growth of timber production has been slow and with low value added. Most of the sales are raw materials and they have not been able to establish a furniture factory.

There is no sophistication of their systems, or quality controls, everything is done in a handmade way (except dairy, which has the expertise of Nestlé). However, when questioning about this situation, the general manager believe that he and the general assembly that elected him have done the right choices: "I am managing based on the Bible and that has been key to our success, the gospel instructs me, guides me, advises me, tells me how to behave, even teaches me that I should not steal, I must share with everyone, because the Bible says: love your neighbor as yourself". There has been a notorious change in the quality of life of the inhabitants of Granja Porcón: women have now an active role in the organization, most of them have large houses made of wood, a stable income, services such as satellite TV, tap water, firewood, transportation from the community to Cajamarca, and every children goes to a school they made with the wood they planted 40 years ago.

\section{Discussion}

Doherty, Haugh and Lyon (2014) argue that hybridity, the pursuit of the dual mission of financial sustainability and social purpose is the defining characteristic of social enterprises. Although these are not profit maximizing entities, they have to generate enough revenue to invest both in social projects and business activities. This phenomenon poses a major challenge in decision making and management within these organizations because 
two different logics subsist: value creation and value appropriation (Santos 2012). The organizational tension might originate from the seek to generate social and environmental value and the need to capture some of that value in order to generate profits. Even more, social enterprises might carry higher operative costs as a result of their social activity, and they usually end up competing with profit maximizing firms in the mainstream capitalist economy, engendering more tensions (Hudson, 2009). In the three cases described in this research, each social enterprise successfully dealt with organizational tensions in different forms (Table 3). Wakami changed its structure and created two different entities, one focused in each logic.

\begin{tabular}{|l|l|l|l|l|}
\hline $\begin{array}{l}\text { Social } \\
\text { Enterprise }\end{array}$ & Organizational Structure & $\begin{array}{l}\text { Priority in decision } \\
\text { making }\end{array}$ & Economic Growth & Social Dimension \\
\hline $\begin{array}{l}\text { Grupo } \\
\text { Ixtlán }\end{array}$ & $\begin{array}{l}\text { Corporate with eight } \\
\text { business units }\end{array}$ & $\begin{array}{l}\text { Economic } \\
\text { growth/competitiveness }\end{array}$ & $\begin{array}{l}\text { Financed within ternal } \\
\text { resources }\end{array}$ & $\begin{array}{l}\text { Secondary priority to } \\
\text { ensure survival in the } \\
\text { long run }\end{array}$ \\
\hline Wakami & $\begin{array}{l}\text { Two business units with } \\
\text { different purpose }\end{array}$ & Both & $\begin{array}{l}\text { One business unit provides } \\
\text { resources to the other }\end{array}$ & $\begin{array}{l}\text { Addressed by one } \\
\text { business unit }\end{array}$ \\
\hline $\begin{array}{l}\text { Granja } \\
\text { Porcón }\end{array}$ & $\begin{array}{l}\text { Single business unit with } \\
\text { six departments }\end{array}$ & Social dimension & $\begin{array}{l}\text { Financed by external } \\
\text { entities through alliances }\end{array}$ & $\begin{array}{l}\text { Primary priority } \\
\text { although losing growth } \\
\text { opportunities }\end{array}$ \\
\hline
\end{tabular}

Table 3. How social enterprises deal with organizational tensions (self-elaboration with primary) data

Granja Porcón privileges social performance, but paradoxically, also affects negatively this outcome. Battilana, Sngul, Pache and Model (2015) found that work integration social enterprises that focus on social performance also indirectly weaken this variable by negatively affecting economic productivity.

The use of resources to build and maintain competitive advantages or addressing stakeholder needs is a source of tensions. Although there might be some investments that favor both objectives, prioritization is needed most of the time. Mason and Doherty (2016) argue that how social enterprises solve organizational tension depend on their ability to abandon logics associated with non-profit organizations in favor of a collective culture of doing business within the organization. This may also explain why the three cases presented in this research have different outcomes: the degree of professionalization of their managers and boards or assemblies could have resulted in the prioritization of a different dimension. Even more, Smith, Besharov, Wessels and Chertok (2012) describe that social enterprises have the risk of starting to look more like a traditional for-profit organization on one hand, or traditional not-for profit organization on the other, depending on the logic that prevails and is continually enforced. This could derive in a social enterprise that can be simultaneously a success in one domain and a failure in the other (Smith et al., 2013). One of the elements that is going to determine the future of social enterprises is their ability to deal with organizational tensions, and also the capacity to design new responses that guarantees different decision making than in for-profit or non-for-profit entities.

\section{Conclusions}

Social enterprises address a social problem (through social impact), and at the same time create economic wealth (profit) through the supply of a product or service. This double purpose has led these entities to position themselves as key actors in promoting development, especially in developing countries. In the search for this double purpose, tensions arise within the organization, which generates different types of strategies and mechanisms to address it. Managing this tension is critical for social enterprises, not only because it allows them to achieve their social and economic mission, but also because they guarantee their long-term sustainability and permanence. The knowledge of these strategies is relevant in contexts where vulnerable population itself is responsible for carrying them out, as in the case of indigenous social enterprises.

Several studies have shown how indigenous social enterprises generate quality of life in the communities where they operate, reducing the patterns of exclusion that have historically characterized these populations. However, few studies examine the mechanisms used by these entities to reduce such tensions in their quest to achieve sustainability and success. This paper presents three different alternatives, as well as the mechanisms and perspectives used by each case, to manage this situation. These results show the diversity and complexity of this phenomenon in indigenous social enterprises, contributing to fill this gap in the literature. 
Although this work contributes to the understanding of the phenomenon, its main limitation is the impossibility of generalizing the results. However, it contributes to the understanding of the tensions between the generation of social and economic value that characterizes social entrepreneurship, and the social innovations that emerge from it.

Future lines of research in this topic could focus on the pressures exerted by different stakeholders in favor of the generation of economic or social value; the governance conditions, level of professionalization, the culture and values that favor one dimension or the other; and the type of capabilities required in the organization when they privilege one of the two dimensions. Likewise, there is an opportunity to continue studying this phenomenon not only in social enterprises emanating from the school of the Social Economy, as is the case of indigenous social enterprises, but also those emanating from the Inclusive Capitalistic Economy school.

\section{Declaration of Conflicting Interests}

The authors declared no potential conflicts of interest with respect to the research, authorship, and/or publication of this article.

\section{Funding}

The authors received no financial support for the research, authorship, and/or publication of this article.

\section{References}

Anderson, R.B., Dana, L.P., \& Dana, T.E. (2006). Indigenous land rights, entrepreneurship, and economic development in Canada: "Opting-in" to the global economy. Journal of world business, 41(1), 45-55.

https://doi.org/10.1016/j.jwb.2005.10.005

Austin, J., Gutierrez, R., Ogliastri, E., \& Reficco, E. (2006). Gestión efectiva de emprendimientos sociales. Lecciones extraídas de empresas y organizaciones de la sociedad civil en Iberoamérica. Edited by SEKN. México, D.F.: Banco Interamericano de Desarrollo.

Bacchiega, A., \& Borzaga, C. (2003). The Economics of the Third Sector. Toward a more comprehensive approach. In H.K. Anheier \& A. Ben-Ner (eds.), The study of Nonprofit Enterprise: Theories and approaches (pp. 27-48). New York: Springer Science \& Business Media. https://doi.org/10.1007/978-1-4615-0131-2_2

Battilana, J., Sngul, M., Pache, A., \& Model, J. (2015). Harnessing productive tensions in hybrid organizations: The case of work integration social enterprises. Academy Of Management Journal, 58(6), 1658-1858. https://doi.org/10.5465/amj.2013.0903

Berkes, F., \& Adhikari, T. (2006). Development and conservation: indigenous businesses and the UNDP Equator Initiative. International Journal of Entrepreneurship and Small Business, 3(6), 671-690. https://doi.org/10.1504/IJESB.2006.010920

Bird, K., Hulme, D., Moore, K., \& Shepherd, A. (2002). Chronic Poverty and Remote Rural Areas. Manchester: IDPM, University of Manchester.

Bitencourt, C.C., Bittencourt Marconatto, D.A., Barin-Cruz, L., \& Raufflet, E. (2016). Introduction to Special Edition Social Innovation: Researching, defining and theorizing Social Innovation. Revista de Administração Macken₹ie, 17(6), 14-19. https://doi.org/10.1590/1678-69712016/administracao.v17n6p14-19

Bizberg, I. (2010). Una democracia vacía. Sociedad Civil, movimientos sociales y democracia. Los grandes problemas de México. El Colegio de México.

Cajaiba-Santana, G. (2014). Social innovation: Moving the field forward. A conceptual framework. Technological Forecasting \& Social Change, 82, 42-51. https://doi.org/10.1016/j.techfore.2013.05.008

Campbell, S. (1998). Social entrepreneurship: how to develop new social-purpose business ventures. Health care strategic management, 16(1), 17-28. 
Caulier-Grice, J., Davies, A., Patrick, R. \& Norman, W. (2012). Defining Social Innovation. A deliverable of the project: "The theoretical, empirical and policy foundations for building social innovation in Europe" (TEPSIE), in European Commission - 7th Framework Programme (1-43). Brussels: European Commission.

Chambers, L. (2014). Growing a bybrid venture: Toward a theory of mission drift in social entrepreneurship. University of St. Gallen.

Comunidades de la Tierra (2018). Dónde trabajamos. Retrieved from: http://www.comunidadesdelatierra.org/comunidades.php (Last access date: July, 2018).

CONEVAL (2015). CONEVAL informa los resultados de la medición de pobreza 2014. Retrieved from: http://www.coneval.org.mx/SalaPrensa/Documents/Comunicado005_Medicion_pobreza_2014.pdf (Last access date: March, 2016).

De Sousa Santos, B. (2001). Los nuevos movimientos sociales. OSAL, September, 177-184.

Dees, J.G. (2007). Taking social entrepreneurship seriously. Society, 44(3), 24-31. https://doi.org/10.1007/BF02819936

Defourny, J. (2001). Introduction: From third sector to social enterprise. In C.Borzaga \& J. Defourny (eds), The Emergence of Social Enterprise (pp. 1-18). London; New York: Routledge.

Defourny, J., \& Nyssens, M. (2008). Social enterprise in Europe: Recent trends and developments. Social Enterprise Journal, 4(3), 202-228, https://doi.org/10.1108/17508610810922703

Defourny, J., \& Nyssens, M. (2010). Conceptions of Social Enterprises in Europe and the United States: Convergences and Divergences. Journal of Social Entrepreneurship, 1(1), 32-53.

https://doi.org/10.1080/19420670903442053

Dey, P., \& Steyaert, C. (2010). The politics of narrating social entrepreneurship. Journal of Enterprising Communities: People and Places in the Global Economy, 4(1), 85-108. https://doi.org/10.1108/17506201011029528

Dey, P., \& Teasdale, S. (2013). Social Enterprise and Dis/identification. Administrative Theory \& Praxis, 35(2), 248-270. https://doi.org/10.2753/ATP1084-1806350204

Di Domenico, M.L., Haugh, H., \& Tracey, P. (2010). Social Bricolage: Theorizing Social Value Creation in Social Enterprises. Entrepreneurship Theory and Practice, 34(4), 681-703. https://doi.org/10.1111/j.1540-6520.2010.00370.x

Díaz, M., Marcuello, C., \& Marcuello, C. (2012). Empresas sociales y evaluación del impacto social. CIRIECEspaña, Revista de Economía Pública, Social y Cooperativa, 75, 179-198.

Doherty, B., Haugh, H., \& Lyon, F. (2014). Social Enterprises as Hybrid Organizations: A Review and Research Agenda. International Journal Of Management Reviews, 16(4), 417-436. https://doi.org/10.1111/ijmr.12028

Foley, D. (2003) An examination of indigenous Australian entrepreneurs. Journal of Developmental Entrepreneurship, $8,133-151$.

Fontan, J.M., Klein, J.L., \& Tremblay, D.G. (2004). Innovation et société: Pour élargir l'analyse des effets territoriaux de l'innovation. Géographie, Économie, Société, 6, 115-128. https://doi.org/10.3166/ges.6.115-128

Fontan, J.M., Klein, J.L., \& Tremblay, D.G. (2005). Innovation socioterritoriale et reconversion économique: Le cas de Montreal. Paris: L’Harmattan.

Friedman, V.J., \& Desivilya, H. (2010). Integrating social entrepreneurship and conflict engagement for regional development in divided societies. Entrepreneurship \& Regional Development, 22(6), 495-514. https://doi.org/10.1080/08985626.2010.488400

Golafshani, N. (2003). Understanding Reliability and Validity in Qualitative Research. The Qualitative Report, 8(4), 597-606.

Harrison, J., Macgibbon, L., \& Morton, M. (2001). Regimes of Trustworthiness in Qualitative Research: The Rigors of Reciprocity. Qualitative Inquiry, 7(3), 323-345. https://doi.org/10.1177/107780040100700305 
Hockerts, K. (2010). Social entrepreneurship between market and mission. Review of Entrepreneurship, 8(2), 177-198.

Howaldt, J., Domanski, D., \& Kaletka, C. (2016). Social innovation: towards a new innovation paradigm. Revista de Administração Mackenzie, 17(6), 20-44. https://doi.org/10.1590/1678-69712016/administracao.v17n6p20-44

Hudson, R. (2009). Life on the edge: Navigating the competitive tensions between the 'social' and the 'economic' in the social economy and in its relations to the mainstream. Journal of Economic Geography, 9(4), 493-510. https://doi.org/10.1093/jeg/lbp005

INEI (2016). Pobreza y gasto social. Retrieved from: https://www.inei.gob.pe/estadisticas/indice-tematico/sociales/ (Last access date: March, 2017).

Kay, C. (2006). Rural Poverty and Development Strategies. Journal of Agrarian Change, 6(4), 455-508. https://doi.org/10.1111/j.1471-0366.2006.00132.x

Kostetska, I., \& Berezyak, I. (2014). Social entrepreneurship as an innovative solution mechanism of social problems of society'. Management Theory and Studies for Rural Business and Infrastructure Development, 36(3), 569-578. https://doi.org/10.15544/mts.2014.053

Le Pennec, M., \& Raufflet, E. (2016). Value Creation in Inter-Organizational Collaboration: An Empirical Study. Journal of Business Ethics, $\mathrm{n}^{\circ}, 1-18$. https://doi.org/10.1007/s10551-015-3012-7

Longo, G., Gerometta, J., \& Ha, H. (2005). Social Innovation and Civil Society in Urban Governance: Strategies for an Inclusive City. Urban Studies, 42(11), 2007-2021. https://doi.org/10.1080/00420980500279851

MacCallum, D., Moulaert, F., Hillier, H., \& Vicari Haddock, S. (2009). Social Innovation and Territorial Development. Burlington: Ashgate Publishing Limited.

Mair, J., \& Martí, I. (2006). Social entrepreneurship research: A source of explanation, prediction and delight. Journal of World Business, 41(1), 36-44. https://doi.org/10.1016/j.jwb.2005.09.002

Mason, C. \& Doherty, B. (2016). A Fair Trade-off? Paradoxes in the Governance of Fair-trade Social Enterprises. Journal Of Business Ethics, 136(3), 451-469. https://doi.org/10.1007/s10551-014-2511-2

Mikami, K. (2014). An alternative framework for the analysis of social enterprises. Journal of Co-operative Organization and Management, 2(2), 92-97. https://doi.org/10.1016/j.jcom.2014.03.005

Morais-da-Silva, R.L. (2016). Scaling up social innovation: A meta - synthesis. Revista de Administração Mackenzie, 17(6), 134-163. https://doi.org/10.1590/1678-69712016/administracao.v17n6p134-163

Moulaert, F., Martinelli, F., González, S., \& Swyngedouw, E. (2007). Introduction: Social Innovation and Governance in European Cities. European Urban \& Regional Studies, 14(3), 195-209. https://doi.org/10.1177/0969776407077737

Murray, R., Caulier-Grice, J., \& Mulgan, G. (2010). The open book of social innovation. London: The Young Foundation.

Nyssens, M. (2006). Social enterprise at the crossroads of market, public policy and civil society. In M. Nyssens (ed.), Social Enterprise: At the Crossroads of Market, Public Policies and Civil Society (pp. 313-328). New York: Routledge.

Orozco-Quintero, A., \& Berkes, F. (2010). The role of linkages and diversity of partnerships in a Mexican community-based forest enterprise. Journal of Enterprising Communities, 4(2), 148-161. https://doi.org/10.1108/17506201011048059

Parker, S.C. (2012). Theories of entrepreneurship, Innovation and the business cycle. Journal of Economic Surveys, 26(3), 377-394. https://doi.org/10.1111/j.1467-6419.2012.00728.x

Paton, R. (2003). Managing and measuring social enterprises. New Delhi: SAGE.

Peredo, A.M., \& Chrisman, J.J. (2006). Toward a theory of community-based enterprise. Academy of Management Review, 31(2), 309-328. https://doi.org/10.5465/amr.2006.20208683 
Peredo, A.M., \& McLean, M. (2006). Social entrepreneurship: A critical review of the concept. Journal of world business, 41(1), 56-65. https://doi.org/10.1016/j.jwb.2005.10.007

Pol, E., \& Ville, S. (2009). Social innovation: Buzz word or enduring term?. The Journal of Socio-Economics, 38(6), 878-885. https://doi.org/10.1016/j.socec.2009.02.011

Portales, L. (2015). Integración de organizaciones y empresas al territorio por medio de innovaciones sociales. Innovaciones de Negocios, 12(23), 1-29.

Portales, L., \& Arandia, O. (2015). Emprendimiento y Empresa Social Como Estrategia De Desarrollo Local. Recherches en Sciences de Gestion, 111(6), 137. https://doi.org/10.3917/resg.111.0137

Portales, L., Arandia, O., \& García de la Torre, C. (2015). Entre survie-développement et respect der normes: Les cas de l'ONG "Pequeños Gigantes". In L. Cappelletti, P. Benoît, \& V. Zardet (eds), Dynamique Normative. Arbitrer et négociar la place de la norme dans l'organisation (pp. 163-172) (1st ed). Paris: Éditions EMS.

Santos, F.M. (2012). A Positive Theory of Social Entrepreneurship. Journal of Business Ethics, 111(3), 335-351. https://doi.org/10.1007/s10551-012-1413-4

Santos, F.M., \& Eisenhardt, K.M. (2009). Constructing markets and organizing boundaries: entrepreneurial action in nascent fields. Academy of Management Journal, 52(4), 643-671.

https://doi.org/10.5465/amj.2009.43669892

Smith, W., Besharov, M., Wessels, A., \& Chertok, M. (2012). A Paradoxical Leadership Model for Social Entrepreneurs: Challenges, Leadership Skills, and Pedagogical Tools for Managing Social and Commercial Demands. Academy Of Management Learning \& Education,11(3), 463-478. https://doi.org/10.5465/amle.2011.0021

Smith, W., Gonin, M., \& Besharov, M. (2013). Managing Social-Business Tensions: A Review and Research Agenda for Social Enterprise. Business Ethics Quarterly, 23(3), 407-442. https://doi.org/10.5840/beq201323327

Spiggle, S. (1994). Analysis and interpretation of qualitative data in consumer research. Journal of Consumer Research, 21(3), 491-503. https://doi.org/10.1086/209413

United Nations (2015). Objetivos de Desarrollo Sostenible, Pobreza - Desarrollo Sostenible. Retrieved from: http://www.un.org/sustainabledevelopment/es/poverty/ (Last access date: December, 2015).

Van Kemenade, S., \& Favreau, L. (2001). Nueva Economía Social y Empleo en Quebec: Hacia una democratización de las relaciones laborales. Quebec: Université du Québec à Hull.

Vázquez-Maguirre, M., \& Portales, L. (2014). La empresa social como detonadora de calidad de vida y desarrollo sustentable en comunidades rurales. Pensamiento y Gestión, 37(Jul-Dic), 255-284.

https://doi.org/10.14482/pege.37.7028

Vázquez-Maguirre, M., Portales, L., \& Velásquez Bellido, I. (2018). Indigenous Social Enterprises as Drivers of Sustainable Development: Insights from Mexico and Peru. Critical Sociology, 44(2), 323-340.

https://doi.org/10.1177/0896920516688757

Wei-Skillern, J., Austin, J., Leonard, H., \& Stevenson, H. (2007). Entrepreneurship in the Social Sector. Thousand Oaks: Sage Publications.

Westley, F., \& Antadze, N. (2010). Making a Difference Strategies for Scaling Social Innovation for Greater Impact. The Innovation Journal: The Public Sector Innovation Journal, 15(2), 1-19.

Intangible Capital, 2018 (www.intangiblecapital.org)

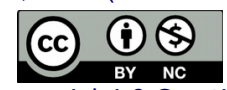

Article's contents are provided on an Attribution-Non Commercial 4.0 Creative commons International License. Readers are allowed to copy, distribute and communicate article's contents, provided the author's and Intangible Capital's names are included. It must not be used for commercial purposes. To see the complete license contents, please visit https://creativecommons.org/licenses/by-nc/4.0/. 